\title{
Mass Incarceration and neoliberal penality: A response to Lloyd and Whitehead's Kicked to the Curb.
}

\author{
Abstract
}

This paper is written in response to Lloyd and Whitehead's (2018) Kicked to the Curb: The triangular trade of neoliberal polity, social insecurity, and penal expulsion. Using the "triangular trade" that underpinned chattel slavery as an analytical metaphor, Lloyd and Whitehead (2018) argue that the growth of mass incarceration is an endogenous feature of neoliberalism. They conclude a distinctive form of penality - neoliberal penality has developed over the past forty years. Lloyd and Whitehead (2018) propose that a tripartite model - neoliberalism, precarity and mass incarceration - as the basis for a model of neoliberal penality. This paper uses an exploration of the arguments raised by Lloyd and Whitehead (2018) to examine the links between neoliberalism and the expansion of the penal state. Whilst recognising the centrality of race to these issues, the paper argues that the model that Lloyd and Whitehead (2018) present offers a partial explanation for mass incarceration. This paper acknowledges that the triangular trade metaphor is a powerful one but will conclude that it has limitations. In particular, the comparison between mass incarceration and chattel slavery is overstated. The economic impact of slavery and its centrality to the modern capitalism (Williams, 2014) cannot be compared to the exploitation that occurs in the current prison system. The paper argues that neoliberalism, precarity and mass incarceration are clearly linked but do not constitute a triangular trade as Lloyd and Whitehead (2018) conclude.

\section{Introduction}

Using the "triangular trade" that underpinned chattel slavery as an analytical metaphor, Lloyd and Whitehead (2018) argue that the growth of mass incarceration is an endogenous feature of neoliberalism. Lloyd and Whitehead (2018) propose a tripartite model - neoliberalism, precarity and mass incarceration "The slave trade of the 170os constituted a triangular trade in human cargo. Critically, there is a contemporary triangular trade, the three limbs of which are neolib- 
eral polity; the reproduction of social insecurity; and the modernised transformation of criminal justice and penal policy in the direction of exclusionary punishment and prison"

\section{Lloyd and Whitehead (2018)}

This paper accepts the centrality of race to these issues and the potential power of the triangular trade as an analytical metaphor. However, it argues that the model that Lloyd and Whitehead (2018) present offers, at best, a partial explanation for mass incarceration. The current paper will argue that Lloyd and Whitehead (2018) focus on an economic reductionist analysis of the rise of mass incarceration excludes broader cultural and social attitudes to crime. The paper argues that as well as an economic shift rightwards, there has been a punitive turn. This shift cannot simply be explained by neoliberal economics even though its roots may be located there. The paper seeks to present a more nuanced understanding of the factors that have played a part in the development of neoliberal penality.

I am using the term mass incarceration here to donate the expansion of the use of imprisonment that has occurred across several jurisdictions in since the early $1908 \mathrm{~s}$ (Simon, 2007). The United States is the country where the rise in the use of imprisonment has been most dramatic. They conclude that a distinctive form of penality neoliberal penality that has developed over the past forty years. The usage of the term neoliberalism itself has been subject to more critical analysis (Garrett, 2019). For some, the term is used so broadly to describe such a range of social, economic and political policies that it has lost its original, theoretical, conceptually and analytical value. Venugopal (2015) is particularly critical of the way that term neoliberalism has been so widely and loosely used. He notes that There were just 103 Google Scholar entries in English with the term 'neoliberal" or 'neoliberalism' in the title between 1980 and 1989. This had multiplied to 1,324 for $1990-9$, and 7,138 for $2000-9$.

Venugopal (2015 p 165/166). 
The electoral successes of politicians influenced by Hayek (2014), Friedman (2009) (and the Chicago School) led to neoliberalism becoming a term that was both 'omnipresent' and 'promiscuous ' (Clarke, 2008, p. 135). Garrett (2019) notes that critics suggest that neoliberalism has become a meta narrative. Neoliberal has become such an elastic term that it is applied across a range of political and economic settings. Dunn (2017) notes that the term has most traction in academia and amongst "left elites". Bourdieu (2001) saw neoliberalism as a "conservative revolution" that sought to overthrow the postwar social democratic consensus.

The key features of neoliberalism include attempts to expand the so-called mechanisms of the market all areas of life. This includes the monetisation of human activity and relationships (Harvey 2005 and Brown, 2015, 2019). Neoliberalism is, on its own terms, committed to a small state and personal freedom. As Lloyd and Whitehead (2018) note this notion of the small state does not apply in the area of penal policy. The USA and the UK have seen huge increases in the numbers of those subject to imprisonment. Neoliberalism is a cultural and social as well as an economic and political phenomenon (Giroux, 2011). In the cultural and social field, Bauman (2008) outlines what he termed a culture of "hyperindividualism" which leads to a loosening and weakening of social and community ties. The various forms of neoliberalism share a commitment to a small state - apart from the area of law and order. This has led to the expansion of the market or market mechanisms into a range of area that were previously seen as the realm of the state. The penal field is one that has seen a number of such developments including the establishment of private prisons, the privatisation of the probation service in England and Wales and the outsourcing of other functions such as the electronic tagging of offenders (Cummins, 2016).Fraser (2016) in her analysis of the rise of Trump and the Brexit vote argued that these shifts marked the end of what she termed "progressive neoliberalism". For Fraser (2016), "progressive neoliberalism" represents an unholy alliance between social progressive values in the area of gender and race, for example, and neoliberal economics. The Clinton and the later Blair administration represent the two best examples of Fraser's progressive neoliberalism 
Lloyd and Whitehead (2018) argue that neoliberalism as an economic and political phenomenon provides a necessary and sufficient explanation for the development of mass incarceration. Support for this analytical approach can be found in the work of Wacquant (2008, 2009a and 2009b, 2012). He argued that the key premises of neoliberalism have been accepted by parties of both the left and the right. In the penal field, the result has been that the key "doxa" of the penal state such as "prison works" "zero tolerance" and "broken windows" policing have been widely accepted, until relatively recently, in an uncritical fashion. The overall outcome has termed the "decline of the rehabilitative ideal" (Garland, 2001). The CJS and other systems focus on the management of "risk" (Beck, 1992, Webb, 2006). Offenders are now regarded as sites of risk rather than marginalised individuals in need of social and welfare support to be reintegrated into the wider society. The act of imprisonment is an act of state violence that impact on individuals, communities and families. In addition, it has huge symbolic significance and value.

Lloyd and Whitehead (2018 p63) note that "It is problematic to forge a seamless triadic relation between the displacement of Keynesian social democracy, the transition towards neoliberalism, urban outcasts, and decisions by the political class to bolster the criminal justice backlash. But this is the real effect of political interventions and policy changes which have accumulated over recent decades."

\section{Mass Incarceration and neoliberal polity}

The rise in the use of imprisonment has been termed mass incarceration and the development of the penal state. It has been one of the most significant social and public policy developments of the past forty years. It has taken place in a number of jurisdictions. It is most apparent in the USA, which has seen the development of a huge prison industrial complex. There are now over two million people in US jails. An oft quoted statistic is that the USA has five per cent of the world's population has over twenty-five per cent of the world's prisoners. In Europe, England and Wales have followed this trend most closely. The expansion of the penal state has occurred over a prolonged period. However, during that the period since the early 1980 s, it is clear that governments in both the USA and the UK have followed policies that were market orientated, sought to reduce the welfare state and were largely accepting of the 
notion that prison acted as a deterrent to offending. Free market economics were on the whole combined with tougher law and order approaches. The political success of Reagan and Thatcher meant that there was a rightwards shift in debates about law and order (Simon, 2007). Parties, nominally of the left or centre left moved to the right on these issues fearing that they would be portrayed as weak on crime or "on the side of the offender".

Hall (2011) recognised that the links between changes in economic, social and cultural change play out in complex ways. In recognising the centrality of cultural values, he was arguing against a purely economic reductionist approach. The intellectual gurus of Thatcherism argued that inequality was an inevitable feature of free market economies. Alongside this, it was argued that free markets would inevitably lead to free societies. Anti-statism and a focus on individualism was at the heart of New Right thinking. The Thatcher and Reagan years were marked by a near veneration as the rich as "wealth creators". Successful companies were presented as work of one individual - usually but not always a white man. This was a modern version of one of the foundational myths of modern capitalism - the self made man. Success was viewed purely in monetary terms. This was not restricted to the wealthy. Signature policies of the Thatcher period such as the sale of council houses and the sale of shares in privatised utilities were presented as opportunities for the "ordinary citizen' to share in the benefits of capitalism - become winners in the market. It was not only important to make money but also to follow patterns of consumption that demonstrated that. This was most apparent in the developing celebrity and lifestyle of the period. This worship of the rich and their lifestyle took a place alongside the denigration of those living in poverty. In the same way that success was the result of individual effort and talent, failure was also presented as being the result of individual failings. It was not the result of structural inequalities and lack of opportunities. pathologising and stigmatising the poor.

In making populist appeals in both the areas of welfare and punishment, Thatcher and Reagan, made claims they were on the side of the individual against the vested interests of the state. In the area of punishment, the state was portrayed as weak and failing to protect the law abiding. In rejecting the post-war consensus in the penal field, they argued that the liberal elites of the CJS allowed people to escape individual 
responsibility for their own actions. The emphasis on broader social factors as contributing to crime were regarded as providing excuses for poor behaviour. Those who committed crimes should be punished because they had taken an individual decision to break the law. A focus on individualism in the economic sphere was reflected in broader attitudes. These include anti-collectivist appeals to those who experience the state, including the welfare state, as bureaucratic and oppressive. Hall et al (2013) outlined the way, in which, the New Right of the mid 1970s presented itself as being on the side of those who worked hard, paid taxes and so on. These processes entailed the othering of groups such as the poor, welfare claimants and offenders.

Lloyd and Whitehead (2018) view the causes as ultimately the result of neoliberal economic policies. Mass incarceration in this model becomes a way of managing the urban poor. This approach, as the authors notes, is influenced by the work of scholars such as Wacquant (2008, 2009a and 2009b, 2012). There are limitations with this approach not the least of which is transporting an analysis so heavily grounded in the US experience and applying it to the UK. There may well be many similarities and it is clear that much of the New Labour discourse on rights and responsibilities was adopted almost wholesale from Clinton's Democrats. However, as Garland (2018) notes it is impossible to talk of one US experience of mass incarceration because of the differences between the fifty states. When comparing penal regimes, it is important to take account of a range of factors Lacey (2008). She argues that liberal market economies have more deeply established notions of individualism and this is one factor in more punitive approaches to penal policy. Calvadino and Dignan (2006) developed a political economy typology of penal regimes neo-liberal, conservative -corporatist, social democratic and oriental corporatist. A focus on economic factors alone becomes reductionist and potentially excludes important factors in any analysis.

Garland (2004) argues that increasingly punitive attitudes reflected social dislocation and the "othering" of social groups - in this case the marginalised urban poor and those from minority communities. Modern approaches to punishment and broader penal policy create an image of the offender as an outsider -someone who by the virtue of committing crime has surrendered future liberty claims. These attitudes 
underpin the call for "tougher" punishments, longer sentences and harsher conditions in prisons. Becker's (1968) model, offenders are making a rational choice to commit crime. Possible punishment or other sanctions are part of a cost benefit analysis that offenders make. Harsher punishment will thus change the nature of these decisions. A more traditional welfare approach sees the roots of offending in personal and social circumstances. A more individualistic society has seen crime to become seen much more as an issue of personal responsibility (Garrett, 2015) argues crime is now seen as the result of lack of individual and social control. In the politics of law and order, populist politicians make direct appeals to voters for the need to be tougher on crime. In making these appeals, liberal elites - policy makers and academics are presented as weak and ineffectual more concerned with human rights of offenders than the impact of crime. Hall et al (2013) highlighted the powerful role such appeals have. Hall (1979) showed that Thatcher in making a series of calls to “ordinary citizens" effectively exploited law and order concerns in her development of populist authoritarianism. In the UK, no politician has been able to shift the debates back to the centre ground since.

Simon (2014) compared the expansion of the use of imprisonment to a biblical flood. a flood that he now sees as past its peak and identifies three elements of phases in the development of mass incarceration. Driven by a fear of crime and the political fallout from being seen as weak on the issues (Simon, 2007), prosecutors ask for custodial sentences where previously a community penalty would have been imposed. Then sentences are increased. Finally, mandatory and or indeterminate sentences are introduced. Garland (2018) argues that the broad explanations of the sort that are offered by metanarratives such as neoliberal penality or a new Jim Crow provided the initial theoretical explanations of the rise of mass incarceration have been challenged by more fine grain analyses that highlight the complex range of local and other factors. He concludes that

The institutional terrain upon which "mass incarceration" was built turns out to be quite varied, as are local penal politics. And although all 50 states and the federal government have increased incarceration, there have been marked difference in the kinds of transformations that have occurred, both quantitatively and qualitatively; and the multiple processes driving prison growth need to be specified and disaggregated 
As Garland (2018) notes the Californian experience is very different to that of the state of Maine. The three strikes law is often quoted as one of the drivers of increased incarceration rates across the USA. However, the way that the law was operated in California led to very significant rises in incarceration rates that did not occur in other states where it was introduced in a different fashion (Zimring et al., 2001). The large-scale narratives of mass incarceration provide many insights and open up theoretical explanations but they also obscure local and other factors that provide a more complete picture. This is as true for nations as it is for the individual states of the USA.

One of the key questions to consider in response to Lloyd and Whitehead is whether it is possible to identify a distinctive neoliberal penality. The starting point for this must be an examination of neoliberalism. The analysis of neoliberalism has concentrated on two very broad areas (Wacquant, 2012). The first is essentially an economic model that examines the application of the "market" and "market forces" to areas of public and private life that were previously seen as 'social goods' or 'beyond the market'. Under the Thatcher Government in the UK, this model was followed in social housing and public utilities. It has since been extended to the penal system and wider aspects of the CJS. Harvey (2005) has described this process as 'accumulation by dispossession". (Nozick, 1974) emphasises the role that the state has in securing and maintaining the liberty of the subject. Thus, the expansion of what he termed the "night-watchman state" is not necessarily inconsistent. From this perspective, increasingly punitive social and penal policies and the expansion of the penal state fits with a schema that it is argued enhance individual liberty. The second but linked perspective is influenced by Foucault's notion of governmentality. These approaches examine the way that power has become de-centralised in late modern capitalist society. This has created a discourse of self-government and regulation as the defining features of citizenship (Foucault, 2008) examines the construction of the modern discourse of citizenship with its emphasis on. In this schema, neoliberalism is characterised as a shift in the relationship between the individual and the state. The goal of the state is therefore to produce self-regulating citizens. 
Wacquant (2012) argues that these two broad approaches 'obscure what is neo about neo-liberalism'. It is a political project that involves the dismantling of welfare provisions. 'Workfare' or 'prisonfare' are the new means of regulating marginal urban populations. These processes involve a rebalancing of what Bourdieu termed the Left and Right hands of the State. For Bourdieu, the Left hand of the State represented what be very broadly termed social welfare-education, health and social work. The Right hand is the police, Courts and penal system. (Wacquant (2012) describes the shift as a move from the protective (feminine and collectivising) to the disciplinary (masculine and individualising). This notion of the state has been criticised for its binary nature. It fails to recognise that agencies on both sides perform what can be broadly termed disciplinary and welfare roles (Garrett, 2007).

Wacquant (2008, 2009a, 2009b and 2012) work provides an analysis of the development of more punitive welfare and penal policies seeing them as integral features of the neoliberal political project. He acknowledges that these shifts are not simply about changes in government and public policy. Neoliberalism adopts what Gramsci (1971) terms a "war of position" against the welfare state. This involves the manufacture of "anti-welfare commonsense" (Jensen and Tyler, 2015) which involves the media and political representation of the welfare state as overgenerous and creating dependency and crime (Cummins, 2018). In this war of position, think-tanks, academics and sympathetic journalists have had a key role in the spreading of the 'doxa' of neoliberalism and the penal state. Wacquant uses the term "doxa" to mean terms that set the parameters of a debate or phrases that commonly used but never properly interrogated. In the economic and social spheres, these would include market, flexibility, choice and individualism. In the penal sphere, phrases such as 'prison works', 'zero tolerance' and 'broken windows" have all become doxa (Wacquant, 2008, 2009a, 2009b). (Wacquant (2008) concludes that the Police, Courts and Prisons now represent 'a core political capacity through which the state both produces and manages inequality, identity and marginality'.

Lloyd and Whitehead (2018) final leg of the modern triangular trade is precarity. Neoliberal economic and political policies have seen an attack on the pay, conditions and rights of workers (Standing, 2011). The shift to a service economy and deindustrialization has seen a decline in the power of organized labour. Union membership 
in the UK, for example, has declined and is now largely concentrated in the public sector workforce. As series of restrictions on the right to organize, picket and strike alongside mass unemployment weakened the power of organized labour in the 1980 s (Young, 2002). Since that time, there has been a rise in short term contracts, the development of the gig economy and wages have stagnated (Wacquant, 2009). One of the strengths of Lloyd and Whitehead's use of the triangular trade metaphor is that it emphasizes the links between these elements of neoliberalism, mass incarceration and precarity. Those who are at most risk of being incarcerated are those who have been discarded by neoliberalism - the urban poor. Alongside precarity in employment, they face increased surveillance and monitoring by the state either by the CJS or the welfare state. Lloyd and Whitehead (2018) argue historical, economic and structural factors combine here and impact disproportionately on racial minorities.

One of the difficulties with Wacquant's thesis and the one presented by Lloyd and Whitehead here, is a deterministic mechanistic link between the rise in rates of imprisonment and the rise of the influence of neoliberal ideas. This minimises the other factors that are potentially at play - for example the influence of a high-profile case or a moral panic about a sort of crime. It is also dependent on a rather monolithic view of governments, failing to recognise the often apparently contradictory policy positions that are adopted. For example, in the UK, in the late 1980s and early 1990s, the Home Office under a liberal Home Secretary Douglas Hurd sought to introduce a range of community-based alternatives to imprisonment all based on the premise that 'prison is an expensive way of making bad people worse' (Gottschalk, 2006).Thatcherism as Hall (1979) pointed out was a mixture of free market economics and traditional Conservative social values. These are not necessary always in alignment. In this case we can see that there is a tension between different areas of government. Hurd became Foreign Secretary, when he was succeeded by the rightwing populist David Waddington. It was the appointment of another, populist Michael Howard as Home Secretary in 1993 led to the rapid expansion of the use of imprisonment in England and Wales. Howard was committed to a penal philosophy based on the notion that as he announced that the Tory Party conference in 1993 'prison works.' In England and Wales, the rate of incarceration increased following this and in the New Labour years (1997- 2010). In the period between June 1993 and June 2012, the prison population in England and Wales increased by 41,800 to over 
86,000 (Ministry of Justice 2013). There is a huge debate about the nature of New Labour but certainly in the period 1997-2005, it oversaw a significant investment in health and social welfare programmes such as Sure Start. The contrast with the current position of welfare systems as outlined in the UN Rapporteur's report (Allston, 2018) could not be starker. The rates of the use of imprisonment continued to rise under New Labour. Blair followed a clear political strategy which meant that he would not be outflanked on crime. He regarded it as a potential vote loser. However, New Labour is also characterised its investment in education, health and other areas is very much at odds with the principles of Hayek (2014) and Friedman (2009). There is something of a parallel here with Hinton's (2016) analysis of the Johnson administration. Progressive social policies combined with increasingly punitive penal and welfare policies. The growth in the use of imprisonment in the UK and USA continued under Clinton and Blair who led nominally progressive parties Wacquant (2009a, 2009b). Alongside the rise in the use of imprisonment, New Labour communitarian influenced wider social policy saw the introduction of a raft of measures such as Anti-Social Behaviour Orders (ASBOs) imposing societal norms on the marginalized (Butler \& Drakeford, 2001).

The legacy of slavery and mass incarceration

Central to Lloyd and Whitehead's (2018) comparative argument is the notion of a triangular trade. The transatlantic slave trade saw the expansion of ports such as Liverpool and Bristol in second half of the eighteenth century. The triangular nature of the trade saw European traders sail to the West African coast. There would purchase slaves in exchange for goods. These ships then transported slaves in appalling conditions across the Atlantic. Those slaves that survived this journey known as the Middle Passage, were sold as slaves to plantation owners. The final leg of the triangle saw these ships sail back to European ports loaded with produce such as sugar, coffee, tobacco, rice and cotton, which had been produced by slave labour. In addition, slaves were bought and sold within the United States. In his seminal work, Capitalism and Slavery, Williams (2014) argued that slavery and the profits that it produced were the engines of the Industrial Revolution. Williams as well as providing an economic analysis of the centrality of slavery to the development of modern capitalism, demonstrated that its legacy in terms of racial attitudes. Williams' work challenged the, at that point, standard representation of moral progress which saw the abolition of the 
slave trade as one of the achievements of Enlightenment inspired Liberalism. He argued that chattel slavery was ultimately destroyed by the forces of modern industrial capitalism.

More recent scholarship across a range of disciplines has explored the way that slavery was inextricably intertwined with the development of major institutions in the UK. For example, Cambridge University has recently announced funding for a research project that will explore how it benefited from bequests and gifts whose source is wealth generated by the slave trade (https://www.theguardian.com/education/2019/apr/30/cambridge-university-study-how-it-profited-colonial-slavery) In 2018, Glasgow University produced a report which concluded that although the University of Glasgow never owned enslaved people or traded in the goods they produced, it is nonetheless clear that the University received significant financial gifts and support from people who derived their wealth from slavery. Mullen and Newman (2018). The report also makes clear that the links between the city of Glasgow and the slave trade. Its historic role as the "second city of the Empire" is inextricably linked is a result of the wealth created by slavery. Hall (2016) shows the way that it was not only large institutions such as banks and Universities that profited from the slave trade. Individuals and families owned slaves and they were valuable assets. However, this history of slave ownership is hiding in plain sight and rarely acknowledged.

Like slavery, mass incarceration generates huge profits. Wagner and Rabuy (2017) outline the overall costs of the US penal state, calculating that it costs the government and families $\$ 182$ billion dollars. This figure $\$ 63,2$ billion dollars spent on criminal law aspects of policing and $\$ 80.7$ billion dollars on public correction agencies. The private sector has an increasing role in the CJS. In the prison system, Wagner and Ruby highlight that prisoners and their families are also charged for goods and services, for example, spending $\$ 1.3$ billion on telephone calls. However, the penal system does not have the role in the exploitation of labour and generation of capital that slavery had in the establishment in the modern world. It is an important area, but it does not have a similarly central role. This does not ignore the injustices of mass incarceration or the ongoing damage that it does to individuals, families and communities. 
Narratives of mass incarceration

The USA's history of slavery, racial segregation and discrimination forms the historical backdrop to Wacquant's analysis the modern penal system. Wacquant (2002) produced an analysis of the modalities of racial oppression in the USA. They are clearly interlinked. In this sense one can draw a line from slavery to mass incarceration. However, it is not a direct parallel as suggested by the Lloyd and Whitehead model. These modalities of oppression share a set of racist beliefs, but they function in different ways.

\begin{tabular}{|c|c|c|c|}
\hline \multirow{2}{*}{$\begin{array}{l}\text { TABLE I } \\
\text { Institution }\end{array}$} & \multicolumn{3}{|c|}{ The four 'peculiar institutions' and their basis } \\
\hline & Form of labour & Core of economy & Dominant social type \\
\hline $\begin{array}{l}\text { Slavery } \\
(1619-1865)\end{array}$ & $\begin{array}{l}\text { unfree fixed } \\
\text { labour }\end{array}$ & Plantation & slave \\
\hline $\begin{array}{l}\text { Jim Crow } \\
\text { (South, } 1865-1965)\end{array}$ & $\begin{array}{l}\text { free fixed } \\
\text { labour }\end{array}$ & $\begin{array}{l}\text { Agrarian and } \\
\text { extractive }\end{array}$ & sharecropper \\
\hline $\begin{array}{l}\text { Ghetto } \\
\text { (North, 1915-68) }\end{array}$ & $\begin{array}{l}\text { free mobile } \\
\text { labour }\end{array}$ & $\begin{array}{l}\text { Segmented } \\
\text { industrial } \\
\text { manufacturing }\end{array}$ & menial worker \\
\hline $\begin{array}{l}\text { Hyperghetto } \\
\text { \& Prison (1968-) }\end{array}$ & $\begin{array}{l}\text { fixed surplus } \\
\text { labour }\end{array}$ & $\begin{array}{l}\text { Polarized } \\
\text { postindustrial } \\
\text { services }\end{array}$ & $\begin{array}{l}\text { welfare recipient } \\
\& \text { criminal }\end{array}$ \\
\hline
\end{tabular}

(Wacquant, 2002)

Race must play a central role in the analysis of mass incarceration. The historical and ongoing overrepresentation of African Americans in the CJS is well documented (Wacquant, 2009a, Drucker, 2011, Alexander, 2012, Hinton, 2018). There are some elements of American exceptionalism at play here. However, it would be a mistake to assume that these issues do not arise in other penal systems. The Lammy Inquiry (2107) highlighted the impact of racism on the experiences of particularly young black men in the UK system. The USA experience is a key element of Lloyd and Whitehead's (2018) argument so it will be examined in some depth here. There is a significant literature that highlights the impact of increasingly punitive law and order 
policies on the African American community. The combination of neoliberal economic policies, the rise of the penal state and legacies of slavery, Jim Crow and other forms of racist exclusion have led to the current position. Hinton (2018) notes that in recent years the gulf between incarceration rates for blacks and whites have narrowed. The statistics remain shocking.

- Black men represent $13 \%$ of the US male population but $35 \%$ of all men serving state or federal sentences of more than a year

- One in three black men born in 2001 can expect be incarcerated at some point in their lifetime. This compares to one in seventeen white men. One in eighteen black women born in 2001 will be incarcerated compared to one in forty-five Latina women and one in hundred and eleven white women.

These figures are not some contemporary aberration. They are the result of historical and contemporary racist processes that have targeted the black community. The backdrop to these CJS figures is the deeply entrenched racist nature of US society that sees African Americans experiencing levels of extreme poverty, economic and educational disadvantage, poor housing and other factors that contribute to crime. In addition, the African American community experiences over policing and a concomitant lack of protection (Brown,2004, Brunson and Miller,2005, Owusu-Bempah 2017 and Baldwin, 2018.) Lloyd and Whitehead (2018) in presenting their metaphor focus on chattel slavery and its impact. Urbina and Pena (2018) demonstrate the American state and the US CJS role in targeting and excluding Latino/Hispanic communities and populations. Trump's border wall and anti-immigrant rhetoric is a modern manifestation of these processes.

The above historical experiences as well as contemporary experiences. The links between the post slavery construction of a racist myth of black criminality and contemporary dog whistle law and order politics are rather underplayed in Lloyd and Whitehead's (2018) argument. Mass incarceration has not solely been driven by racist ideas, but the centrality of their role has to be examined. The $13^{\text {th }}$ Amendment abolished slavery but there is an exception for those convicted of a crime. Blackmon (2008) shows that this loophole was used to target newly emancipated former slaves. 
Blackmon (2008) shows the key role that the convict leasing system had in the key areas - for example on former plantations but also mining and railways. He shows that, for example, the rates of arrests for "vagrancy" offences increased in line with seasonal demands for labour. The outcome of these two strategies was the incarceration of black people at higher rates. This then became the basis for a series of racist tropes about the alleged nature of black criminality that remain deeply engrained within US political debates. Haney- Lopez (2014) has explored the way that politicians can exploit these by making dog whistle calls to votes - using coded language or phrases that appeal to racist tropes without using racist terms. Trump has done this on numerous occasions - though he does not exactly blow a dog whistle but use a racist megaphone. The most recent being his attacks on the African-American congressman Elijah Cummings (https://www.theguardian.com/us-news/2019/jul/27/donald-trump-elijah-cummings-democrat-house-oversight-bully-rat-rodent)

The historical and contemporary overrepresentation of African Americans in the CJS is thus based on a range of wider social, economic and political factors. However, as Muhammed (2010) notes the high arrest and incarceration rates have led to what he terms a "statistical discourse". In this discourse, the factors that led to higher arrest and incarceration rates are ignored. The rates themselves are used to inform political and popular debates. These debates then shift the focus from the historic legacy of slavery and modern structural factors to the so called failings of the African American family, for example, the absence of male role models. There is an explicit link between welfare and penal policy here. Attacks on the welfare state from the Right have focused on its alleged profligacy, creation of dependency and the extent of fraud within the system. Anti-welfare on the Right has been linked with racist and anti-immigrant discourses (Cummins, 2018). Murray's (1990, 1994 and 2012) notion of the underclass is constructed in largely racist terms. Meade (1992) in his attacks on the role of the welfare state does so in dog whistle terms. Reagan political use of the "welfare queen" and the media reporting of it made calls to deeply entrenched constructions of black female sexuality (Kohler-Hausmann, 2015). In the 1988 Presidential election, George Bush (Snr) Willie Horton attack ad on Dukakis played on series of stereotypes of the dangers posed by black male sexuality that can be traced back to slavery (Saul, 2017). 
Alexander (2012) argues that mass incarceration and the policies linked to it have created a new caste of socially excluded young African American males. This includes those who are incarcerated but also formerly incarcerated individuals who are denied the full rights of citizenship - including often the right to vote - and who struggle to find employment. Alexander (2012) concludes that these developments have put the gains of the Civil Rights era under pressure. There is a similar pattern to the postCivil War period where the CJS and policing undermine political and social progress. Laws are not written in the explicitly racist fashion of the late $19^{\text {th }}$ century. However, Hinton (2018) demonstrates that laws that are, at face value, racially neutral impact disproportionately on black people. The most important example of this is the wider War on Drugs. For example, policies such as drug- free zones and habitual offender laws have a greater impact on African Americans. The Black Lives Matter movement, the high profile cases such as the deaths of Michael Brown in Ferguson and Sandra Bland in Texas have raised public awareness of the extent of police violence against African Americans.

Racism is a long-standing issue in the CJS. It existed before the dominance of neoliberal social and economic policies. Therefore, the triadic module proposed by Lloyd and Whitehead does not fully take account of these historical factors and their role in the development of modern penal policy. Lloyd and Whitehead (2018) present mass incarceration as an inevitable outcome of neoliberal economic and social policies arguing it is a way of managing and disciplining urban, minority communities. Wilson (2011, 2012) outlined the devastating impact of deindustrialisation on the urban poor. The development of the service economy saw the loss of relatively well paid unionised jobs. The jobs that replaced in the service sector where often part-time and certainly did not carry with them health care and other benefits. To the huge challenges that poor urban communities faced was added the damage done by drugs and related crime. These issues disproportionately impacted on African-American communities.

There is what might be termed a "standard narrative of mass incarceration". This is, perhaps, most closely associated with Alexander (2012). The broad thrust of this argument is that the War on Drugs in the 1970s and 8os resulted in a huge rise in 
the prison population in the USA. The rise was mainly driven by the incarceration of millions of people for low-level drugs offences. The War on Drugs was targeted at poor urban areas. This exacerbated the already massive racial disparities within the US criminal justice system. Alexander (2012) argued that these moves created a new caste system. It is not simply the overrepresentation of black males in the prison population that needs to be considered. Alexander (2012) outlines the way that a whole series of measures such as felon disenfranchisement laws and housing laws mean that formerly incarcerated persons are excluded from civic society. The new caste was predominately African American. Alexander (2012) argues that these developments have to be seen in the context of the wider politics of race and the civil rights movement. Mass incarceration and its aftermath here is understood as part of an attempt to undo the progress that of the mid-1960s.

This narrative is challenged by the US legal scholar (Pfaff, 2017). It should be emphasized that Pfaff (2017) is arguing for prison reform and an end to mass incarceration. However, his work in challenging the traditional narrative of the expansion of the penal state, also calls for a different approach to ending it. There are two major areas where Pfaff (2017) departs from previous explanations. The first is the nature of offences that drove the development of mass incarceration to the turning point of 2010 where prison numbers began to fall. Pfaff (2017) argues that it is violent offences rather than low level drug offending that are the main driver of the expansion of the prison population. These offences may well be, in many instances, related to drugs. Pfaff (2017) makes the hugely significant point here that the response to concerns about rises in violent offending has been to be call for longer tougher sentences. To reduce the prison population effectively, will require something of a shift in wider societal attitudes. Longer sentences for serious offences are often politically justified by populist narrative that they not only punish individuals and protect potential future victims, but they also demonstrate the strength of outrage and disgust at such offences. There is an implicit assumption here that a long period of imprisonment is what all victims of violent crime want to happen to the perpetrators (Simon, 2007). Such notions are based on an individualized analysis of the core drivers of violence that see such offenders as somehow cut off from the wider society (Sered, 2019). This allows us to ignore the structural drivers of violence, inequality, racial discrimina- 
tion, poverty, poor housing, poor education and the lack of community services (Wilkinson and Pickett, 2009). Sered (2019) argues that the core features of the penal state, racism, social shaming and the exposure to brutality mirror the factors that result in people being incarcerated. Thus, the official policy responses to violence are based on the very features that create it. In looking at alternatives to long prison sentences as responses to violent crime, both Pfaff (2017) and Sered (2019) acknowledge that this will involve often difficult societal conversations about the nature and value of punishment

The second area where Pfaff (2017) departs from the standard narrative is in his discussion of the role of the federal government. He argues that the focus on federal issues obscures the fact that prison systems at the local and state level lie at the root of the mass incarceration. This, therefore, requires a deeper analysis of the specifically local factors that are responsible for the rises in the use of imprisonment. For example, Parsons (2018) in her examination of the closure of asylums in Pennsylvania, a state that had one of the largest mental health systems in the post war USA, shows that the failures of deinstitutionalisation, a fear driven politics of mental illness and fiscal conservatism combined so that that closing mental hospitals helped to feed the expansion of incarceration. The importance of the work of scholars such as Parsons is that it highlights that local factors played a rise in incarceration rates so they must also play one reducing them. Broader lessons can clearly be drawn. For example, Parsons (2018) work emphasises that wider investment in mental health services must form part of the work that will end mass incarceration. Finally, Pfaff (2017) places a focus on the role of prosecutors. He argues that prosecutors make hugely significant decisions about who is charged, the nature of the charges but also in plea bargains. He sees this group as one of the key drivers of increased use in imprisonment - often in the name of victims -but their role is little discussed and is largely out of the political spotlight. Pfaff (2017) argues that mass incarceration is an ineffective way to combat crime, particularly in there is limited support for those who released from prison. The estimated $\$ 80$ billion that is spent on prisons and jails does not include the wider financial, social, emotional and physical costs that mass incarceration imposes on individuals, families and communities. The reframing mass incarceration as an issue of human and civil rights, rather than one of law and order, means that these broader societal harms can be properly acknowledged. 


\section{Ending Mass Incarceration}

If we are to see parallels between slavery and mass incarceration, then one area to consider in more depth is how "the peculiar institution" was abolished. What are the lessons that can be drawn? Lloyd and Whitehead (2018) do explore these issues. However, they focus initially on the work of reformers such as Wilberforce. Hague's (2007) biography of Wilberforce features prominently in the early part of the paper. It is only in the concluding section that the broader abolitionist movement is examined. This seems to underestimate the potential analytical and generative power of the triangular trade metaphor.

There are parallels between the forces that led to the abolition of slavery and modern movements to end mass incarceration. There is a growing movement, now, largely based in the USA that is calling for reform of the CJS and the end to mass incarceration. This movement is includes organisations - Black Lives Matter - think tanks such as Vera Institute, the Stop Mass Incarceration Network as well as local community groups and academics. For example, the Vera Institute explicitly frames as a civil rights one

America is at a tipping point. In a country that continues to lead the world in locking up its own people, mass incarceration has emerged in recent years as a defining civil rights issue. A movement has blossomed in which formerly incarcerated people lead alongside diverse and influential allies, powerfully capturing what's at stake: that runaway use of incarceration dehumanizes poor people and people of color, damages already marginalized communities, does not advance public safety, and siphons public resources with no social benefit.

As in the abolitionist movement, the media has been used every effectively to raise awareness and discussion of the issues. Alexander's (2012) The New Jim Crow received wide media coverage and became a driver for reform. Eugene Jarecki's 2012 documentary The House I live In traces the impact of the War on Drugs. The impact of the War on Drugs across David Simon's five season TV epic The Wire. The Wire though not a commercial success at the time has been subsequently lauded as one of 
the greatest shows on US television. Set in Baltimore, it examines the wider social impacts of deindustrialisation alongside the impact of the War on Drugs (Penfold Mounce et al 2011). In presenting mass incarceration as an issue of civil rights, these campaigns refer not only to the campaigns of the 1960 s but also the era of slavery. Alexander (2012) explicitly makes this comparison.

The issue of mass incarceration has risen up the US domestic political agenda. In July,2015 President Obama became the first sitting president to visit a federal prison. In 2016, Hillary Clinton came under attack, for her use of the term - super predators the remark was made in a 1996 speech in New Hampshire, where Clinton spoke in support of the 1994 Violent Crime Control and Law Enforcement

Just as in a previous generation we had an organized effort against the mob. We need to take these people on. They are often connected to big drug cartels; they are not just gangs of kids anymore. They are often the kinds of kids that are called superpredators - no conscience, no empathy. We can talk about why they ended up that way, but first, we have to bring them to heel." The 1994 Act was a being a key piece of legislation that led to increased numbers of African Americans being incarcerated. Ironically, Donald Trump, described her use of the term as racist and asked if she had ever apologised. Bennett et al (1996) notion of the super predator can be viewed as a modern reiteration of long-standing racist stereotypes of young black men. It was very influential and predicated that levels of teenage offending - particularly violent offending would increase dramatically by the turn of the century. In the 2019, Democratic primary debates former Vice-President Joe Biden came under pressure for his role in the development of mass incarceration.

\section{Conclusion}

Lloyd and Whitehead (2018) present a powerful and polemical attack on the development of the penal state. The development of mass incarceration cannot be separated from other social and economic changes. The growth in inequality and the shredding of the welfare state (Giroux, 2011) are clearly drivers of the prison boom. These are features of neoliberalism. The attack on the social state has been a sustained one that 
has lasted over forty years but has been accelerated in the UK by the policy of austerity that was introduced by the Coalition Government in 2010. Austerity's architects may have presented it as a response to a national emergency. However, its main aim of shrinking the role of the welfare state places it firmly in the libertarian tradition that flows from Hayek (2014) and Friedman (2009). The demonisation of the poor as feckless and work shy shares key elements with Murray (1990). In fact, its roots can be traced back to Booth's representation of poverty in Victorian London (Cummins, 2018). Welshman (2013) demonstrates the way that problem families and communities have been rediscovered and redefined at fairly regular intervals ever since. In this tradition, poverty is regarded not as a structural issue. Its causes are the individual moral failings of the poor. As Lloyd and Whitehead (2018) show the retrenchment of the welfare state has been accompanied by the expansion of the penal state. "Workfare" and "prison fare" can thus be regarded as deeply interconnected.

Lloyd and Whitehead's (2018) argue that the growth of mass incarceration and the development of the penal state is an endogenous feature of neoliberalism. They conclude that there is a distinctive form of penality - neoliberal penality that has developed over the past forty years. Lloyd and Whitehead propose that a tripartite model neoliberalism, precarity and mass incarceration. They compare this model to the triangular slave trade which saw humans and goods being traded across the Atlantic. In presenting this triadic model, there is an implicit comparison between slavery and mass incarceration. Whilst recognising the centrality of race to these issues, the model that Lloyd and Whitehead present offers, at best, a partial explanation for mass incarceration. The current prison system is a site of the exploitation of labour. Prisoners being paid meagre wages to fight forest fires being a recent example (https://www.vox.com/2018/8/9/17670494/california-prison-labor-mendocino-carr-ferguson-wildfires). Major corporations in the USA and elsewhere are making profits from virtually all aspects of incarceration. The prison regime is increasingly brutal and violent. A series of reports from individual prisons and HMIP have highlighted appalling conditions in jails in England and Wales. Hall (2016) have highlighted the ways that not only major institutions for example banks and leading Universities but also citizens made profits from the slave trade. There are echoes of this in the way that major corporations have invested in aspects of the penal state. Through shareholding and pension funds individuals are also connected to the prison industrial complex. 
The question here is whether this stands comparison to the role of chattel slavery in the development of modern capitalism. The economic impact of slavery and its key role in the foundation of modern capitalism (Williams, 2014) far outweighs the ex-

ploitation that occurs in the current prison system. The "triangular trade" that was at the heart of the slave trade is a key element of Lloyd and Whitehead's comparison. The links between neoliberalism and modern penal policy are not as well defined and clear cut as those between the legs of the triangular trade. Whilst in no way defending conditions in prison or the injustices of the current of the modern penal system in the UK and the USA, chattel slavery and all its horrors remains distinct. Mass incarceration and the racial discrimination inherent within it may be viewed as one of its legacies.

\section{References}

Alexander, M (2012) The New Jim Crow; Mass Incarceration in the Age of Colorblindness New York. New Press

Baldwin, B., (2018). Black, White, and Blue: Bias, Profiling, and Policing in the Age of Black Lives Matter. W. New Eng. L. Rev., 40, p.431.

Bauman, Z (2008) The Art of Life Cambridge Polity Press

Beck, U (1992) Risk Society: Towards a New Modernity London Sage

Becker, G.S., (1968), Crime and punishment: an economic approach, Journal of Political Economy 76,169-217.

Bennett, W. J., Dilulio, J. J., \& Walters, J. P. (1996). Body count: Moral poverty ... and how to win America's war against crime and drugs. New York, NY: Simon \& Schuster.

Blackmon, D (2008) Slavery by Another Name: the Re-enslavement of Black Americans from the Civil War to World War II New York Anchor Books

Bourdieu, P. (2001). Acts of Resistance: Against the New Myths of Our Time Cambridge: Polity Press.

Brown, L.K., (2004). Officer or overseer: Why police desegregation fails as an adequate solution to racist, oppressive, and violent policing in Black communities. NYU Rev. L. \& Soc. Change, 29, p.757.

Brown, W., (2015). Undoing the demos: Neoliberalism's stealth revolution. Mit Press. 
Brown, W., (2019). In the Ruins of Neoliberalism: The Rise of Antidemocratic Politics in the West. NY Columbia University Press.

Brunson, R.K. and Miller, J., (2005). Young black men and urban policing in the United States. British journal of criminology, 46(4), pp.613-640.

Butler, I. and Drakeford, M., (2001). Which Blair project? Communitarianism, social authoritarianism and social work. Journal of Social Work, 1(1), pp.7-19.

Cavadino, M. and J. Dignan (with others) (2006) Penal Systems: A Comparative Approach. London: Sage Publications

Clarke, J., 2008. Living with/in and without neo-liberalism. Focaal, 2008(51), pp.135-147.

Cummins, I., (2016). Mental Health and the Criminal Justice System: A social work perspective. Northwich Critical Publishing.

Cummins, I., (2018). Poverty, inequality and social work: The impact of neo-liberalism and austerity politics on welfare provision. Bristol Policy Press.

Drucker, E (2011) A Plagues of Prisons; The Epidemiology of Mass Incarceration in America New York. New Press

Dunn, B., (2017) Against neoliberalism as a concept. Capital \& Class, 41(3), pp.435454 .

Foucault M (2008) The Birth of Biopolitics: Lectures at the Colle 'ge de France, 1978-79. New York: Palgrave

Fraser, N., (2016). Progressive neoliberalism versus reactionary populism: A choice that feminists should refuse. NORA-Nordic Journal of Feminist and Gender Research, 24(4), pp.281-284.

Friedman, M., (2009). Capitalism and freedom. Chicago University of Chicago Press.

Garland, D (2001) The Culture of Control Crime and Social Order in Contemporary Society Oxford. OUP

Garland, D (2004) Beyond the Culture of Control Critical Review of International and Political Philosophy Vol 7 (2) 160-189

Garland, D., (2018). Theoretical advances and problems in the sociology of punishment. Punishment \& Society, 2o(1), pp.8-33.

Garrett, P. M. (2007). Making social work more Bourdieusian: Why the social professions should critically engage with the work of Pierre Bourdieu. European Journal of Social Work, 10(2),225-243. 
Garrett, P (2015) Confronting neoliberal penality: Placing prison reform and critical criminology at the core of social work's social justice agenda Journal of Social Work Garrett, P.M., (2019). Revisiting 'The Birth of Biopolitics': Foucault's Account of Neoliberalism and the Remaking of Social Policy. Journal of Social Policy, 48(3), pp.469-487.

Giroux, H (2011) Neoliberalism and the death of the social state: remembering Walter Benjamin's Angel of History Social Identities: Journal for the Study of Race, Nation and Culture Volume 17, Issue 4,

Gramsci, A. (1971). Selections from the prison notebooks (Q. Hoare \& G. NowellSmith, eds. \& trans.). New York: International Publishers

Hague, W., (2007). William Wilberforce: The life of the great anti-slave trade campaigner. Houghton Mifflin Harcourt.

Hall, C., (2016). Writing History, Making 'Race': Slave-Owners and Their Stories. Australian Historical Studies, 47(3), pp.365-380.

Hall, S., (1979) The great moving right show. Marxism Today, 23(1), pp.14-20.

Hall, S., Critcher, C., Jefferson, T., Clarke, J. and Roberts, B. (2013) Policing the Crisis (35th Anniversary edition) Palgrave Basingstoke

Haney-López, I., (2014). Dog whistle politics: How coded racial appeals have reinvented racism and wrecked the middle class. Oxford, Oxford University Press.

Harvey, D. 2005. A Brief History of Neoliberalism, Oxford: Oxford University.

Hayek, F.A., (2014) The road to serfdom: Text and documents: The definitive edition. London Routledge.

Hinton, E., (2016). From the War on Poverty to the War on Crime. Cambridge Harvard University Press.

Hinton, E (2018) An Unjust Burden: The Disparate Treatment of Black Americans in the Criminal Justice System New York Vera Institute of Justice Jarecki, E., (2012). The house I live in. Produced by Melinda Shopsin.

Jensen, T., \& Tyler, I. (2015). 'Benefits broods': The cultural and political crafting of anti-welfare common sense. Critical Social Policy, 35(4), 1-22

Kohler-Hausmann, J., (2015). Welfare crises, penal solutions, and the origins of the “welfare queen". Journal of Urban History, 41(5), pp.756-771.

Lacey, N (2008): The Prisoners' Dilemma: Political Economy and Punishment in Contemporary Democracies. Cambridge. Cambridge University Press. 
Lammy, D (2017) An Independent Review into the Treatment of, and Outcomes for, Black, Asian and Minority Ethnic Individuals in the Criminal Justice System London: National Audit Office

Lloyd, A. and Whitehead, P., 2018. Kicked to the Curb: The triangular trade of neoliberal polity, social insecurity, and penal expulsion. International Journal of Law, Crime and Justice, 55, pp.60-69.

Lopez, G (2018) California is using prison labor to fight its record wildfires https://www.vox.com/2018/8/9/17670494/california-prison-labor-mendocinocarr-ferguson-wildfires

Mead, L (1992) The New Politics of Poverty: The Nonworking Poor in America NY Basic Books

Muhammed, Khalil Gibran. (2010). The Condemnation of Blackness: Race, Crime, and the Making of Modern Urban America. Cambridge Harvard University Press: Mullen, S. and Newman, S., (2018). Slavery, abolition and the University of Glasgow. Report and recommendations of the University of Glasgow History of Slavery

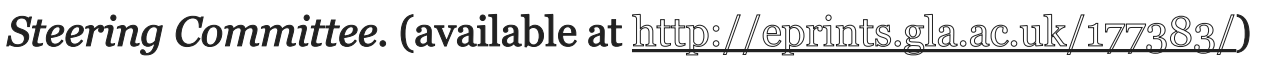
Murray C (1990) The Emerging British Underclass (Choice in Welfare) London IEA Murray, C (1994) Losing Ground: American Social Policy, 1950-198o NY Basic Books

Murray, C (2012) Coming Apart: The State of White America, 1960-2010 NY Random House

Nozick, R (1974) Anarchy, State and Utopia Blackwell Oxford

Owusu-Bempah, A., (2017). Race and policing in historical context: Dehumanization and the policing of Black people in the 21st century. Theoretical Criminology, 21(1), pp.23-34.

Parsons, A.E., (2018). From Asylum to Prison: Deinstitutionalization and the Rise of Mass Incarceration After 1945. UNC Press Books.

Penfold-Mounce, R., Beer, D. and Burrows, R., (2011). The Wire as social science-fiction? Sociology, 45(1), pp.152-167.

Pfaff, J., (2017). Locked In: The True Causes of Mass Incarceration-and How to Achieve Real Reform. Basic Books.

Saul, J.M. (2017) Racial Fig leaves, the Shifting Boundaries of the Permissible, and the Rise of Donald Trump. Philosophical Topics, 45 (2). pp. 97-116. 
Sered, D., (2019). Until We Reckon: Violence, Mass Incarceration, and a Road to Repair. NYC The New Press.

Simon, J., (2007). Governing through crime: How the war on crime transformed American democracy and created a culture of fear. Oxford, Oxford University Press.

Simon, J (2014) Mass Incarceration on Trial: A Remarkable Court Decision and the Future of Prisons in America New York, The New Press,

Urbina, M.G. and Peña, I.A., 2019. Crimmigration and militarization: Policing borders in the era of social control profitability. Sociology Compass, 13(2), p.e12654.

Venugopal, R., 2015. Neoliberalism as concept. Economy and Society, 44(2), pp.165187.

Wacquant, L (2002) From Slavery to Mass Incarceration New Left Review 41-60

Wacquant, L (2008) Urban Outcasts: A Comparative Sociology of Advanced Marginality

Cambridge. Polity Press

Wacquant, L (2009a) Prisons of Poverty Minneapolis. UM Press

Wacquant, L (2009b) Punishing the Poor the Neoliberal Government of Social Insecurity

Durham Duke University Press

Wacquant, L. 2012. Three steps to a historical anthropology of actually existing neoliberalism Social Anthropology 20(1): 66-79.

Wagner, P. and Rabuy, B., (2017) Following the money of mass incarcera-

tion. Prison Policy Initiative https://www.prisonpolicy.org/fact-

sheets/money2017.pdf

Webb, S. (2006) Social Work in a Risk Society: Social and Political Perspectives, Basingstoke: Palgrave Macmillan

Welshman, J (2013) Underclass: A History of the Excluded since 1880 London Bloomsbury

Wilkinson, R and Pickett, K (2009) The Spirit Level: Why Equality is Better for Everyone London. Penguin

Williams, E., (2014). Capitalism and slavery. UNC Press Books.

Wilson, W.J., (2011). When work disappears: The world of the new urban poor.

London Vintage. 
Wilson, W.J., (2012). The truly disadvantaged: The inner city, the underclass, and public policy. Chicago University of Chicago Press.

Zimring, F. E., Hawkins, G., \& Kamin, S. (2001). Punishment and democracy: three strikes and you're out in California. Oxford: Oxford University Press. 